\title{
Comparison of feeding and defecation patterns between fifth- instar nymphs of Triatoma patagonica (Del Ponte, 1929) and Triatoma infestans (Klug, 1934) under laboratory conditions
}

\author{
Comparação dos padrões alimentar e de defecação em ninfas de \\ quinto estádio de Triatoma patagonica (Del Ponte, 1929) e \\ Triatoma infestans (Klug, 1934), em condições de laboratório
}

\author{
Claudia Susana Rodríguez ${ }^{1}$, Silvia Alejandra Carrizo $^{1}$ and Liliana Beatriz Crocco ${ }^{1}$
}

\begin{abstract}
Among the vectors of Chagas disease, Triatoma patagonica is a species in the process of adaptation to the human environment. However, its vector competence is not well known. This study had the aim of evaluating and comparing feeding and defecation patterns among fifth-instar nymphs of Triatoma patagonica and Triatoma infestans that were fed ad libitum. The results showed that nymphs of Triatoma patagonica had a feeding pattern similar to that of Triatoma infestans. Sixty nine percent and 58\% of nymphs of Triatoma patagonica and Triatoma infestans, respectively, produced their first defecation within five minutes after being fed. Triatoma patagonica defecated during feeding, with an average time until first defecation that was shorter than that of Triatoma infestans (3.4 and $6.2 \mathrm{~min}$, respectively). The nymphs of Triatoma patagonica were capable of defecating during or immediately after feeding.
\end{abstract}

Key-words: Peridomestic vector. Vector capacity. Chagas disease vector. Triatoma patagonica. Triatoma infestans.

\section{RESUMO}

Entre os vetores da doença de Chagas, Triatoma patagonica é uma espécie que se encontra em processo de adaptação ao ambiente humano; embora sua competência vetorial não seja bem conhecida. 0 estudo teve como objetivo avaliar e comparar padrões de alimentação e defecação em ninfas de quinto estádio de Triatoma patagonica e Triatoma infestans ad libitum. Os resultados mostraram que as ninfas de Triatoma patagonica apresentou padrõe de alimentação semelhante a Triatoma infestans. Sessenta e nove por cento e 58\% das ninfas de Triatoma patagonica e Triatoma infestans respectivamente, realizaram a primeira defecação cinco minutos após de serem alimentadas; sendo que a primeira defecou durante a alimentação, com um tempo médio de dejeção menor do que para Triatoma infestans (3,4 vs 6,2 respectivamente). As ninfas de Triatoma patagonica foram capazes de defecar durante ou imediatamente após de se alimentarem.

Palavras-chaves: Vetor peridoméstico. Capacidade vetorial. Vetor da doença de Chagas. Triatoma patagonica. Triatoma infestans.

In the transmission cycle from Trypanosoma cruzi Chagas, 1909 , to humans, the peridomestic area is showing increasing importance because progressive control over the main domestic vector species of Triatominae may provide opportunities for other species of Triatominae to become epidemiologically relevant ${ }^{2} 416$.

Among the peridomestic vectors of Chagas disease, Triatoma patagonica has the most southerly distribution. This vector is only found in Argentina, at latitudes of $20^{\circ}$ to $50^{\circ}$ south $^{38}$, and it has been reported in domestic and peridomestic areas in the provinces of Rio Negro ${ }^{7}$ and Chubut ${ }^{16}$, Argentina. Susceptibility of this species to infection with Trypanosoma cruzi has been demonstrated experimentally $y^{9}$ and also naturally ${ }^{1}$. Regarding its efficiency as a vector, Nattero et $\mathrm{al}^{10}$ suggested that females of Triatoma patagonica would be capable of transmitting Trypanosoma cruzi, because they defecate while feeding on the host.

The biological characteristics of greatest impact on the epidemiology of Chagas disease involve the feeding and defecation processes of the vector ${ }^{15}$. Fifth-instar nymphs and females constitute the most important fractions of the population, from an epidemiological point of view, since nymphs take more blood

\footnotetext{
1. Cátedra de Introducción a la Biología, Facultad de Ciencias Exactas, Físicas y Naturales, Universidad Nacional de Córdoba, Córdoba, Argentina. This work received financial support from Secretaría de Ciencia y Técnica de la Universidad Nacional de Córdoba. Argentina (SeCyT).

Address to: Biól. Claudia Rodríguez. Cátedra de Introducción a la Biología/Facultad de Ciencias Exactas, Físicas y Naturales/Universidad Nacional de Córdoba. Av. Vélez Sársfield 299, X5000JJC, Córdoba, Argentina.

Tel: $54351433-1056$.

e-mail: claudiarodriguez@efn.uncor.edu

Recebido para publicação em 17/09/2007

Aceito em 29/07/2008
} 
than adults, ingesting between eight and nine times their body weight ${ }^{1114}$.

In order to better understand the efficiency of Triatoma patagonica in Trypanosoma cruzi transmission, the aim of this study was to evaluate the feeding and defecation patterns of fifthinstar nymphs of this species and to compare them with those of nymphs of Triatoma infestans, which is the principal domestic vector in Argentina.

\section{MATERIAL AND METHODS}

This study was carried out with 62 and 55 fifth-instar nymphs of Triatoma patagonica and Triatoma infestans, respectively. The insects used in this study came from laboratory colonies of the insectary of the National Chagas Service (Argentina). Nymphs of Triatoma patagonica were the seventh generation obtained from insects collected in chicken coops at the locality of Monte Fiori, Santa Fe, Argentina, and nymphs of Triatoma infestans were the second generation obtained from insects collected in peridomestic areas at the locality of Loma Blanca, La Rioja, Argentina.

The experiment was carried out between September and December 2005, in a laboratory under constant temperature conditions $\left(26^{\circ} \mathrm{C} \pm 1^{\circ} \mathrm{C}\right)$ and relative humidity $(60 \pm 10 \%)$. The bugs were kept in glass jars, covered with nylon mesh and provided with vertically placed strips of paper. The nymphs were starved for 15 days after molting. Then, they were allowed to feed ad libitum on restrained pigeons (Columba livia Gemelin, 1789). The pigeons were not given anesthesia during the insects' meal. The nymphs were observed continuously during feeding and for $30 \mathrm{~min}$ afterwards. For each feeding, the following variables were observed:

Blood meal size. This was determined as the difference in weight between before and after feeding.

Duration of feeding. This was obtained by recording the time elapsed (in minutes) from the time when the insect's rostrum came into contact with the host's skin until the time when the rostrum was detached.

Number and frequency of defecations by the insect during feeding and within $\mathbf{3 0}$ min after feeding. The number of defecations was registered by direct observation of the insect while it was on the host and for $30 \mathrm{~min}$ after feeding.

All weights were measured using a Mettler balance with a precision of $0.001 \mathrm{~g}$. The duration of feeding and frequency of defecations by the insects were timed using a stopwatch. To compare the meal sizes between nymphs of different species of different body sizes, a relative meal size index (RMS) was obtained: RMS = meal size (mg)/insect weight before feeding (mg).

The t-test for samples with independent variables was used as the statistical treatment for comparing the variables of different species. Correlations between variables were investigated using standard liner regression. To verify the homogeneity of variance, the Levene test was used ${ }^{6}$.

\section{RESULTS}

Feeding patterns. The variables analyzed with regard to the feeding behavior of fifth-instar nymphs of Triatoma patagonica and Triatoma infestans are shown in Table 1. The nymphs of Triatoma patagonica needed significantly more time than did the nymphs of Triatoma infestans to feed to repletion. The two species ingested similarly sized blood meals, but Triatoma patagonica had greater ingestion capacity than presented by Triatoma infestans, ingesting up 3.52 times its body weight.

Table 1 - Feeding behavior of fifth-instar nymphs of Triatoma patagonica and Triatoma infestans.

\begin{tabular}{|c|c|c|c|c|c|c|}
\hline \multirow[t]{2}{*}{ Species } & \multicolumn{3}{|c|}{$\begin{array}{l}\text { Duration of feeding } \\
\qquad(\min )\end{array}$} & \multicolumn{2}{|c|}{$\begin{array}{l}\text { Blood meal size } \\
\quad(\mathrm{mg})\end{array}$} & \multirow[b]{2}{*}{ RMS } \\
\hline & $\mathrm{n}^{\mathrm{o}}$ & $\mathrm{x}$ & SD & $\mathrm{x}$ & $\mathrm{SD}$ & \\
\hline Triatoma patagonica & 62 & $21.40^{*}$ & 9.82 & 128.76 & 79.33 & 3.52 \\
\hline Triatoma infestans & 55 & $12.42^{*}$ & 6.69 & 143.30 & 68.00 & 2.67 \\
\hline
\end{tabular}

*nymphs of Triatoma patagonica differed significantly from nymphs of Triatoma infestans $(\mathrm{p}<0.05)$, RMS: relative meal size, $\mathrm{x}$ : mean, SD: standard deviation

As expected, blood meal size (mg) presented a correlation with duration of feeding $(\mathrm{min})$ in both species (Triatoma patagonica $\mathrm{r}=0.54 ; \mathrm{p}<0.05 ; \mathrm{n}^{\circ}=62 ;$ and Triatoma infestans $\mathrm{r}=0.53$; $\left.\mathrm{p}<0.05 ; \mathrm{n}^{\mathrm{o}}=55\right)$. The regression analysis between the initial weight (mg) and the blood meal size (mg) showed a significant positive linear correlation to nymphs of Triatoma infestans $\left(\mathrm{r}=0.34 ; \mathrm{p}<0.05 ; \mathrm{n}^{\mathrm{0}}=55\right)$, such that higher weight nymphs ingested more blood. No significant relationship was found between these variables for the nymphs of Triatoma patagonica.

Defecation patterns. From the total number of fifth-instar nymphs feeding of both species, $84 \%\left(\mathrm{n}^{-}=52\right)$ of Triatoma patagonica and $75 \%\left(\mathrm{n}^{-}=41\right)$ of Triatoma infestans defecated while feeding and within the first $30 \mathrm{~min}$ thereafter.

Figure 1 shows that $69 \%$ and $58 \%$ of the nymphs of Triatoma patagonica and Triatoma infestans respectively, had produced their first defecation within five minutes after feeding. Ten minutes after feeding, the values recorded were $92 \%$ and $80 \%$ for Triatoma patagonica and Triatoma infestans, respectively.

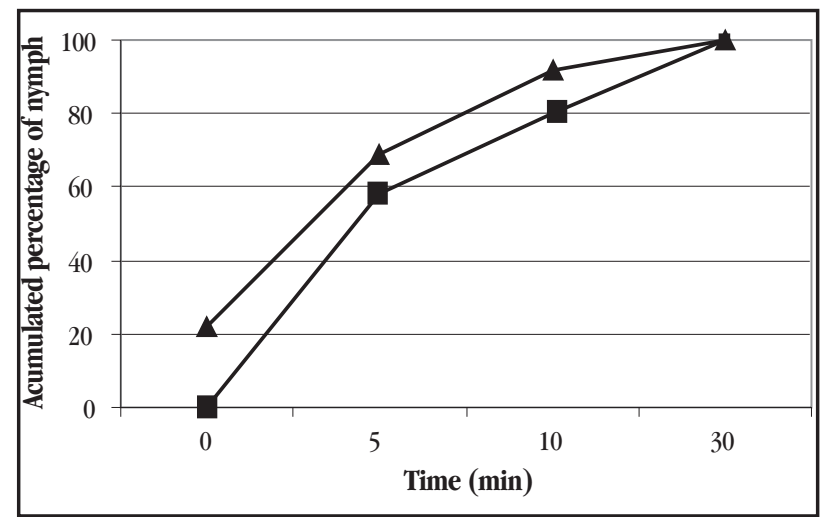

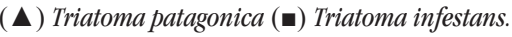

Figure 1 - Accumulated percentages of fifth - instar nymphs of Triatoma patagonica and Triatoma infestans witch defecated during feeding (time 0) and at different times afterwards. 
The average numbers of defecations produced per insect within 5, 10 and $30 \mathrm{~min}$ after feeding were significantly higher for nymphs of Triatoma patagonica than for nymphs of Triatoma infestans: $20 \%$ of specimens of Triatoma patagonica defecated during feeding (time 0 ), with an average time to first defecation that was shorter than that of Triatoma infestans (Table 2).

\begin{tabular}{|c|c|c|c|c|c|}
\hline \multirow[t]{2}{*}{ Species } & \multirow{2}{*}{$\begin{array}{l}\text { First time } \\
\text { defecation } \\
\quad(\min )\end{array}$} & \multicolumn{4}{|c|}{ Number of defecations per insect } \\
\hline & & $0 \mathrm{~min}$ & $\begin{array}{c}5 \min \\
(\min -\max )\end{array}$ & $10 \mathrm{~min}$ & $30 \mathrm{~min}$ \\
\hline $\begin{array}{l}\text { Triatoma } \\
\text { patagonica }\end{array}$ & $3.39 \pm 5.41^{\mathrm{a}}$ & $\begin{array}{c}0.29 \pm 0.66^{\mathrm{b}} \\
(0-3)\end{array}$ & $\begin{array}{c}0.92 \pm 089^{\mathrm{C}} \\
(0-4)\end{array}$ & $\begin{array}{c}1.39 \pm 1.25^{\mathrm{d}} \\
(0-6)\end{array}$ & $\begin{array}{c}2.24 \pm 1.87^{\mathrm{e}} \\
(0-9)\end{array}$ \\
\hline $\begin{array}{l}\text { Triatoma } \\
\text { infestans }\end{array}$ & $6.22 \pm 7.08^{\mathrm{a}}$ & $\begin{array}{l}0.00^{\mathrm{b}} \\
(0-2)\end{array}$ & $\begin{array}{c}0.56 \pm 0.71^{\mathrm{c}} \\
(0-3)\end{array}$ & $\begin{array}{c}0.94 \pm 0.95^{\mathrm{d}} \\
(0-5)\end{array}$ & $1.73 \pm 1.39^{\mathrm{e}}$ \\
\hline
\end{tabular}

a, b, c, d, e: nymphs of Triatoma patagonica differed significantly from nymphs of Triatoma infestans $(\mathrm{p}<0.05)$

Relationship between blood meal size and defecation pattern. In both species, blood meal size was significantly greater among nymphs that defecated $(149.7 \pm 73.4$ and $164.9 \pm 62.1$ $\mathrm{mg}$ for nymphs of Triatoma patagonica and Triatoma infestans, respectively) than among nymphs that did not defecate (67.3 \pm 81.8 and $80.0 \pm 39.3 \mathrm{mg}$ for nymphs of Triatoma patagonica and Triatoma infestans, respectively) $(\mathrm{p}<0.05)$.

Regression analysis on blood meal size at the time of first defecation did not show any significant correlation in either species.

For the nymphs of Triatoma patagonica that defecated, the blood meal size was correlated with the number of defecations per insect within five minutes after feeding $(\mathrm{r}=0.2796 ; \mathrm{p}<0.05$; $\mathrm{n}^{0}=52$ ). In Triatoma infestans, no significant relationship was found.

\section{DISCUSSION}

Comparison between the RMS observed for Triatoma patagonica in the present study and for other peridomestic species by other authors shows that the capacity of nymphs of Triatoma patagonica (3.52) is lower than that of nymphs of Triatoma sordida $(4.10)^{5}$ and higher than that of nymphs of Triatoma guasayana $(2.23)^{13}$. As seen with other Triatominae ${ }^{51013}$, in fifth-instar nymphs of Triatoma patagonica the blood meal size controls the excretion behavior, i.e. the frequency of defecations within the first five minutes after feeding is directly related to the blood meal size.

On the other hand, transmission of Trypanosoma cruzi is crucially dependent on the defecation time. The most efficient vectors are those that defecate during or soon after feeding, while the bug is still in contact with its host ${ }^{18}$. Fifth-instar nymphs of Triatoma patagonica not only defecated quickly after feeding, but some of them (20\%) also defecated during the feeding. However, in our experiment, nymphs of Triatoma infestans did not defecate at these times. Nevertheless, Zeledón et al ${ }^{18}$ observed that about $5 \%$ of the nymphs of Triatoma infestans defecated during feeding.

Comparison of the defecation patterns observed in this study among nymphs of Triatoma patagonica and Triatoma infestans showed that the nymphs of Triatoma patagonica were more efficient in terms of average time to first defecation and number of defecations per insect at different times during the first 30 min after feeding. Zeledón ${ }^{17}$, considered that defecation within $10 \mathrm{~min}$ after feeding appeared to present the highest risk for transmission of Trypanosoma cruzi. The percentage of nymphs of Triatoma patagonica that defecated within this time was approximately $90 \%$ (to do this required a minimum ingestion of $86.5 \mathrm{mg}$ ), while for Triatoma infestans it was $80 \%$. Comparing this percentage with those for other peridomestic species, it can be seen that fifth-instar nymphs of Triatoma patagonica present a pattern that is similar to those shown for Triatoma sordida $(88 \%)^{5}$ and for Triatoma guasayana $(89.3 \%)^{13}$.

The results obtained here suggest that, like the peridomestic species Triatoma guasayana and Triatoma sordida, the fifthinstar nymphs of Triatoma patagonica have a feeding pattern that is similar to the pattern shown by Triatoma infestans, and they are capable of defecating during or immediately after feeding. These conditions would allow nymphs of Triatoma patagonica to transmit Trypanosoma cruzi.

In Triatominae, factors like the dependence of defecation time on the quantity of blood ingested have important implications for disease transmission ${ }^{15}$. However, other factors like the density inside the home, the affinity with the host and the degree of adaptation to the human dwelling are also epidemiologically important with regard to determining this potential ${ }^{12}$. It would be important to continue with studies on the relationships of biological and morphological characteristics with the capacity of Triatoma patagonica to colonize domestic habitats.

\section{ACKNOWLEDGMENTS}

We thank Dr. J. Nattero for collaboration during data collection and Dr. A.L. Carbajal for kindly reviewing the manuscript. Our thanks also to the National Chagas Service (Argentina) for supplying the insects. This work was developed during doctoral studies in Biological Sciences at the Facultad de Ciencias Exactas, Físicas y Naturales, Universidad Nacional de Córdoba, Córdoba, Argentina.

\section{REFERENCES}

1. Abalos JW, Wygodzinsky P. Las Triatominae Argentinas (Reduviidae, Hemiptera), Monograph 2, Instituto de Medicina Regional, Tucumán, Argentina, 1951.

2. Bos R. The importance of peridomestic environmental management for the control of the vectors of Chagas disease. Revista Argentina de Microbiología 20: 58-62, 1988 .

3. Carcavallo RU, Casas SC, Sherlock IA, Galindez Giron JG, Jurberg J, Galvão C, Segura CAM, Moireau F. Geographical distribution and altitudinal and latitudinal dispersion. In: Carcavallo RU, Giron JG, Juberg J, Lent H (eds) Atlas of Chagas Disease Vectors in the Americas, Rio de Janeiro, FIOCRUZ, Volume III, p.747-792, 1999. 
4. Cecere MC, Gürtler RE, Vazquez-Prokopec GM, Kitron U. Patrón espacio-temporal de la reinfestación por Triatoma infestans, vector del Mal de Chagas, en áreas rurales del noroeste argentino. Eco-Epidemiología. II Reunión Binacional de Ecología (Arg-Chile), 2004

5. Crocco LB, Catalá SS. Feeding and defaecation patterns in Triatoma sordida. Memórias do Instituto Oswaldo Cruz 91: 409-413, 1996.

6. Ferrán-Aranaz M. SPSS para windows. Análisis estadístico. Mc Graw-Hill, España, p. 19-28, 110-115, 2001

7. Ferrero AA, Visciarelli EC, Torno 0, Costamagna SR. Presencia de Triatoma patagonica en viviendas humanas en la ciudad de Río Colorado, Provincia de Río Negro. Revista de la Sociedad Entomológica Argentina 58: 79-84, 1999.

8. Lent H, Wygodzinsky P. Revision of the triatominae (Hemiptera, Reduviidae), and their significance as vectors of Chagas' disease. Bulletin American Museum of Natural History 163: 286-288, 1979.

9. Mazza S. Posición Sistemática de Euritriatoma (Triatoma) patagonica. Publicación de la Misión de Estudios de las Patologías Regionales Argentinas 30-17, 1937.

10. Nattero J, Crocco LB, Rodríguez CS. Feeding and defaecation behaviour of Triatoma patagonica (Del Ponte, 1929) (Hemiptera: Reduviidae). Memórias do Instituto Oswaldo Cruz 97: 1063- 1065, 2002.
11. Perlowagora-Szumlewicz A. Species and stage interaction in the feeding behaviour of vectors of Chagas' disease. Revista Instituto de Medicina Tropical São Paulo 15: $139-150,1973$.

12. Piesman J, Sherlock IA. Acta Tropica 40: 351-358, 1983.

13. Rodríguez CS, Crocco LB, Nattero J. Competencia vectorial de Triatoma gusayana (Hemiptera: Reduviidae): patrón de alimentación y excreción. Revista de la Sociedad Entomológica Argentina 63: 11-16, 2004.

14. Schofield CJ. Triatominae: Biología y Control. Eurocomunica Publications, UK, 77 pp, 1994

15. Trumper EV, Gorla DE. Density-dependent timing of defecation by Triatoma infestans. Transactions of the Royal Society of Tropical Medicine and Hygiene 85: 800-802, 1991

16. Wisnivesky-Colli C, Vezzani D, Pietrokovsky SM, Scurti H, Iriarte J. Ecological characteristics of Triatoma patagonica at the southern limit of its distribution (Chubut, Argentina). Memórias do Instituto Oswaldo Cruz 98: 1077-1081, 2003.

17. Zeledón R. Effects of triatomine behavior on trypanosome transmission. Pan American Health Organization Science Publication 318: 326-329, 1975.

18. Zeledón R, Alvarado R, Jiron LF. Observation of the feeding and defecation of three Triatominae species (Hemiptera, Reduviidae). Acta Tropica 34: 65-77, 1977. 